Radnorshire (1912), by Mr. Lewis Daries, is described as a pastoral county with many sheep-walks, with no coal, no sea-coast, and no river of commercial utility, but formed of valleys, moorlands, and a mountainous tract, known as Radnor Forest. Míany good views of the physical features are given, including the great artificial lake of the Caregddu Reservoir in the Elan valley constructed for the watersupply of Birmingham. The geology relates almost wholly to Ordovician, Silurian, Old Red Sandstone, and Igneous rocks. Brief accounts of them, of glacial phenomena, of mineral springs, and stone quarries are given.

\title{
VI.-BRIEF Notices.
}

1. Nonth of England Geologx.--Some points of general interest are mentioned in a paper on " Lamprophyre Dykes in Long Sleddale, Westmorland" by Mr. Alfred Harker in the September number of The Naturalist. The bearing of these dykes is E.N.E., directly towards the Shap granite, 4 miles distant, and one peculiarity is the occurrence of numerous small spherical structures, the result of oozing-in of the final residual magma (wholly felspathic in composition) into steam-cavities. The same part contains a popular" geological account of "The Evolution of Bridlington", by Mr. T. Sheppard, who contributes also an account of a lithographed map of South Yorkshire by William Smith, the "Father of English Geology". This map, dated 1819, and reproduced by Mr. Sheppard, has hitherto escaped record.

2. Geological Map of Norith America.--Under the title Geologic Map of North America the United States Geological Surrey has published (dated 1911) a new and much improved edition of the map described by me in the Grological Magazine for 1906, p. 564. The price of the complete map in four sheets is 75 cents or 38 . carriage free. The scale is $1: 5,000,000$ or 78.9 miles to 1 inch. In the first edition only twentr-five divisions of rocks were shown. In the new edition forty-two divisions are indicated. Another improvement is the insertion of additional place-names, which enable one to identify localities better. Several of the blank spaces in the first edition are now geologically coloured, e.g. Nevada, Idaho, California, Arizona, New Mexico, Baja California, Yukon, and part of Alaska. One cannot help envying the Americans, whose Government, unlike our own, supplies such excellent maps at so low a price.-B. HoBson.

\section{OORRFSPONJDEINOF.}

\section{THE DEVONSHIRE CHALK CLIFFS.}

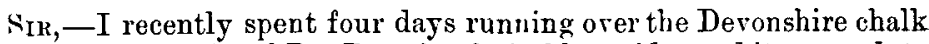
cliffs with the help of Dr. Rowe's admirable guide, and it seemed to me that he had not done quite full justice to those west of Branscombe Mouth. 
He attributes all the flinty chalk seen to the west of the bluff in Branscombe West Cliff, described on p. 25, to the Rhynchonella Cuvieri-chalk, except for the tops of the first two or three bluffs. 'The latter are easily recognizable and all lie well to the east of the 'Camp' on Berry Cliff. But in the south-west face of the 'Camp', about 20 vards east of the cart track leading into the undercliff, there is a bluff quite 25 feet high accessible from top to bottom and composed exclusively of normal (flinty) Terebratulina gracilis-chalk, and there are four similar bluffs, first one by itself, and then three close together, in the cliff some way further west. Again, just east of the fence which runs down the cliff under Littlecombe Hollow there is a bluff which is probably continuous with two small exposures a few feet eastwards of it, the higher of which is composed of normal T. gracilis-chalk. The estimate of 60 feet of flinty R. Cuvieri-chalk, if based on the assignment to that zone of all the flinty chalk seen beyond Littlecombe Hollow, may therefore be excessive.

These exposures of 7 . gracilis-chalk are not expressly mentioned in the very full official account of these cliffs given in The Cretaceous Rocks of Britain, but it may be intended to cover them.

Incidentally I may add that the very curious Metopaster cornutus occurs in the flintless as well as in the flinty $R$. Cuvieri-chalk, though the reverse might have been expected.

27 TwyFord Mansions, Marylebone Street, $\mathrm{W}$.

R. M. BRYDONE. October 9, 1912.

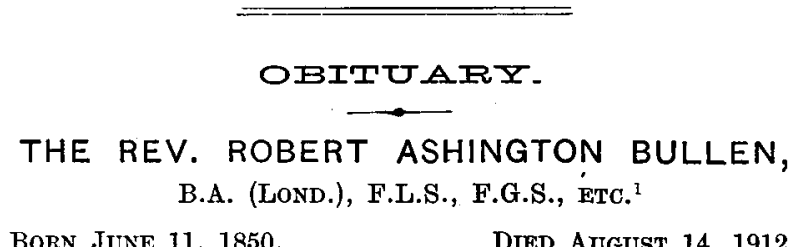

(WITH A PORTRAIT, PLATE XXIV.)

IT is with sad regret we record the loss of our valued friend Mr. Ashington Bullen, who passed away suddenly on August 14, 1912 , in his 63rd jear.

Born at St. George's, Bermuda, on June 11, 1850, he had but a short acquaintance with his birthplace, his parents returning to England with their children when he was only 6 years of age. That he retained a love for his birthplace is shown by his making a special expedition to the Bermudas and subsequently publishing a very interesting account of the geology of the group (see GEoL. MAG., 1911 , pp. 385-95 and 433-42), very fully illustrated.

R. A. Bullen settled with his parents on the south coast and was sent to a private school at Gosport, where he received his early education,

\footnotetext{
'Mr. Bullen's death was recorded in the September Number of the GEoL. MAG., p. 432.
} 